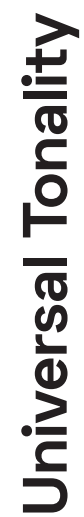


DUKE UNIVERSITY PRESS

DURHAM AND LONDON

2021 

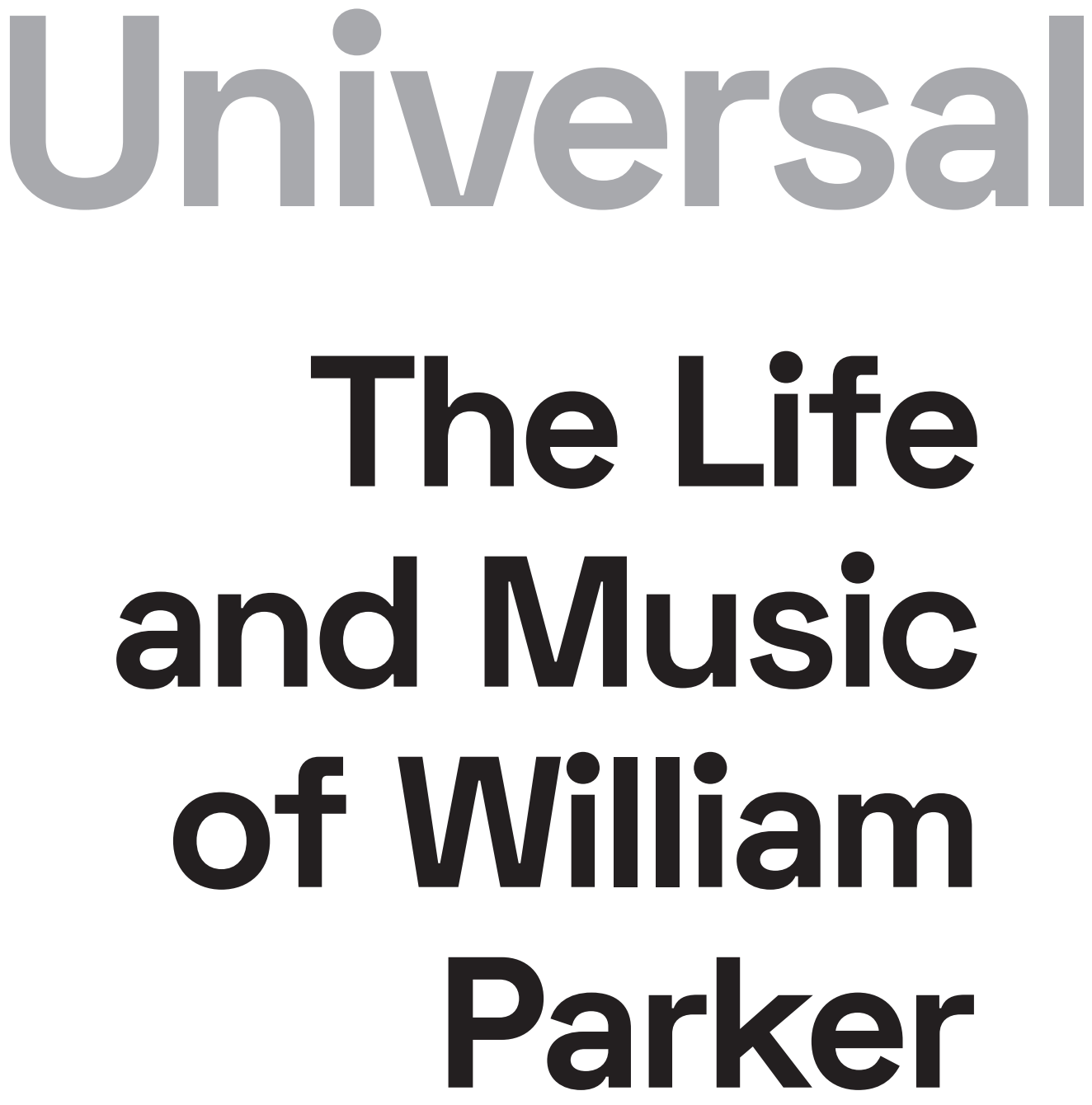

Cisco Bradley

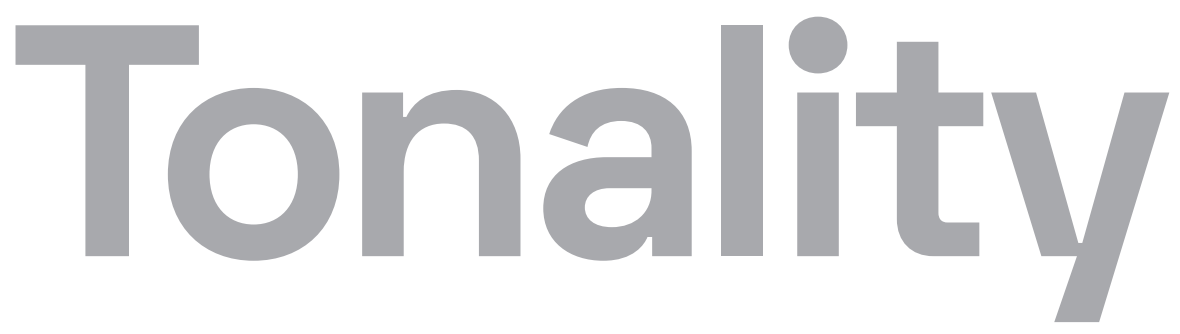


(C) 2021 DUKE UNIVERSITY PRESS

All rights reserved

Printed in the United States of America on acid-free paper $\infty$ Designed by Matt Tauch

Typeset in Arno Pro and Space Grotesk

by Westchester Publishing Services

Library of Congress Cataloging-in-Publication Data

Names: Bradley, Francis R., author.

Title: Universal tonality : the life and music of William Parker /

Cisco Bradley.

Description: Durham : Duke University Press, 2021. |

Includes bibliographical references and index.

Identifiers: LCCN 2020027300 (print) | LCCN 2020027301 (ebook)

ISBN 9781478010142 (hardcover)

ISBN 9781478011194 (paperback)

ISBN 9781478012719 (ebook)

Subjects: LCSH: Parker, William, [date] | Double bassists-

United States_Biography. | Jazz musicians_-United States-

Biography. | Composers-United States-Biography. | Free JazzUnited States-History and criticism.

Classification: LCC ML418.P268 B73 2021 (print)|

LCC ML418.P268 (ebook) | DDC 787.5092 [B]o—dc23

LC record available at https://lccn.loc.gov/2020027300

LC ebook record available at https://lccn.loc.gov/2020027301

Cover art: Photograph by Jimmy Katz. (C) Jimmy Katz. 


\section{To my parents}

SUSANNA LOUISE (REMPLE) BRADLEY (b. 1946), teacher, and CHARLES CRANE BRADLEY JR. (b. 1944), pacifist and social worker, who selected trombone for me to play in sixth grade, which led me to jazz 
This page intentionally left blank 